\title{
Translation Implication for Cultural and Literary Equivalence in Translating Fairy Tales
}

\author{
Piro Tanku \\ Aleksander Moisiu University, Durres, Albania \\ Email: piro.tanku@gmail.com
}

\section{Doi:10.5901/ajis.2013.v2n2p463}

\begin{abstract}
Translation studies and translation criticism, because of the nature and intertwine of many applied disciplines such as linguistic and literary stylistics, linguistics, semiotics, pragmatic, aesthetic, psychology and sociology have attracted and continue to attract the attention of many researchers. In this context, note that there are different cultural problems arising from the translation of fairy tales for children. Relevant methods, the implementation procedures, etc., should not underestimate the practical aspect, the combination of theoretical analysis of translation practice with translations developing further cooperation and communication between researchers and translators. Stated this, it is a delicate situation for translator to translate fairy tales as the reader and listener of such educative and instructive texts are children themselves.Adaptations and using the proper methods of translation is a key to the success of the translator job, as he/she needs to bear in mind the children's world and imagination.
\end{abstract}

Keywords: translation, functionalist approach, cultural implication, methods of analysis, fairy tale

\section{Introduction}

In today's high-tech, mass-media culture, considering the importance of fairy tales may seem ancient in thought and action. Fairy tales are often "deemed of marginal cultural importance and dismissed as unworthy of critical attention. Teachers have reported that fairy tales are not an integral part of children's culture, and, therefore, their messages are of little consequence. This dismissive attitude underestimates the pervasive power of the tales. Indeed, in our high-tech, mass-media culture we are surrounded by the vestiges of fairy tales from the marketing of Disney products to the perpetuation of romance ideology, the binary positioning of women and men, and women's and girls' obsession to manifest socially defined beauty. Fairy tales are sites for the construction of appropriate gendered behavior. Although fairy tales are certainly not solely responsible for the acculturation of children, they are an integral part of the complex layering of cultural stories and influences that affirm and perpetuate cultural norms. Fairy tales constitute a kind of "script" for acceptable forms of feminine and masculine behavior, and they facilitate the production of such behavior by "creating positions to occupy". Fairy tales contribute to the formation of the boundaries of agency, subjectivity, and anticipated rewards. They are powerful cultural agents that tell us how to be. Yet it is impossible to know the exact role stories unconscious and in creating positions for us to take up. While we cannot know precisely how and to what extent fairy tales affect the unconscious, we do know that fairy tale storylines are specific to historical and cultural contexts, and because we ourselves are products of those contexts, we tend to accept the gendered discourse embedded in them as natural, essential, and conclusive. A primary goal of child construction in many cultures is to prepare young human beings for all life situation expectancies. Fairy tales establish appropriate desire as well as appropriate behavior. As the reader's or listener's attention is drawn to desires, values, and sanctioned behaviors, young girls and boys appropriate them as their own. As children recognize themselves and their friends as well as their desires, struggles, and fears in fairy tales, they identify with the characters, especially when those characters reaffirm what they already know through cultural discourse. Thus, young human beings appropriate the position and subjectivities of the hero. What is possible and acceptable for the protagonist becomes possible and acceptable for the reader. Fairy tales and their influence are alive and well and with us today, and it is indeed important that we examine the messages embedded in them: messages that help define the subject positions available to our children. The best possible study can be done in Albania and around the region of the Grimm Brother Fairy Tale Collection seen this time on the translation perspective. 


\section{Modern analysis}

Modern psychologists and cultural anthropologists theorize that the stories that are often read to children at bed-time in the West are actually representations of emotional angst, fear of abandonment, parental abuse, and/or sexual development. The child psychologist Bruno Bettelheim in his book The Uses of Enchantment believes the familiar Grimms' fairy tales to be Freudian myths. A modern editor of the Brothers Grimm and interpreter of the fairy tales tradition is Jack Zipes. The most prolific writer on Grimm's fairy tales in Germany today is Eugen Drewermann who has interpreted more than twenty of the tales psychologically as stories that speak about various struggles on our way to become and to be fully human.

\section{Linguistic}

In the very early 19th century, the time in which the Brothers Grimm lived, the Holy Roman Empire had just met its fate, and Germany as we know it today did not yet exist; it was basically an area of hundreds of principalities and small or midsized countries. The major unifying factor for the German people of the time was a common language. There was as yet no significant German literary history. So part of what motivated the brothers in their writings and in their lives was the desire to help create a German identity.

Less well known to the general public outside Germany is the Brothers Grimm's work on a German dictionary, the Deutsches Wörterbuch. Indeed, the Deutsches Wörterbuch was the first major step in creating a standardized "modern" German language since Martin Luther's translation of the Bible from Latin to German. Being very extensive it is still considered the standard reference for German etymology.

The brother Jacob is recognized for enunciating Grimm's Law, Germanic Sound Shift that was first observed by the Danish philologist Rasmus Christian Rask. Grimm's Law was the first non-trivial systematic sound change ever to be discovered.

\section{We have quite a few known elements from fairy tales here:}

1. Protective parent who can't protect the children. This time this is mother. In Sleeping Beauty it was father. In Snow White it was father at first and then the dwarfs.

2. Missing father, known from so many fairy tales of brothers Grimm. Actually we have a positive male role of a miller (in some versions baker) who knows a wolf plans something mean but similarly to the hunter in Snow White the fear for his survival is stronger than his concerns and he helps the wolf to disguise his paw.

3. Big bad wolf. Yes, we know him from many fairy tales and he is not always in negative role, but his most memorable appearances are exactly these: chasing The Three Little Pigs or tricking Little Red Riding Hood. In the story with seven little goats we can find similarities with both classic fairy tales. Wolf tries to enter three houses of three pigs (remember: he comes to little goats three times) and he falls asleep after eating the granny and Red Cap just to be loaded with stones.

4. We shall not forget the motif of intruder who gets into a locked house thanks to good disguise. In Snow White this is the witch and wolves were for many centuries closely connected with witchcraft. There were even official trials against wolves in the time of inquisition.

5. Cabin in the woods. It seems in many fairy tales most important things happen in forest in the place where ultimate confrontation can happen without third party interfering. Red Riding Hood, Hansel and Gretel, Wolf and seven Kids, Snow White... Or maybe some other important life changing event happens, like princess meets a frog in Frog Prince or princess lost her authority in The Goose Girl... Even in Sleeping Beauty, where the princess never left her home, the forest came to her rescue!

6. Rebirth or resurrection. If we have to pick only one fairy tale to compare it with Wolf and Seven Goats, this would be Little Red Riding Hood. The scene of opening the body to bring back to life something it supposed to be already dead, is so strong, we really don't have better alternative. And the punishment with stones only confirms our decision. 


\title{
Analysis of The wolf and seven little goats:
}

What make this fairy tale stand out from the others is its almost mythic themes of life and death and rebirth. We have two opposing main characters set up against each other in a battle over the lives of seven children. On the one hand a selfcentered, devouring dark wolf who wishes to kill and eat the children. On the other is a self-sacrificing, saving light mother who wishes to protect and nurture the children. In between them are the mother goat's seven kids who have to learn to distinguish between the two.

The fairy tale opens with the mother saying good-bye to her children as she is going into market to buy food for her family. She tells the children not to let anyone in but her and to beware the big bad wolf. He has black fur denoting his evil while the mother has white fur denoting her purity and goodness. She also tells the children that the wolf has a deep gruff voice while hers is soft and melodic. The children promise their mother they will remember all of this and off she goes to market. Not long after she leaves there is a knock at the door and a voice calls out that it is their mother returned and that she has brought a goody for each of the children. The children hear the rough voice and taunt the wolf saying that they know it is him and they are not going to let him in. The wolf leaves and goes to a shopkeeper where he buys and eats a lump of chalk, which apparently softened his voice. I don't want to think about how the original story-teller found that out about chalk. Anyway, the wolf returns with a nice soft voice and calls for the children again and again promises them goodies. Unfortunately for the wolf the children see his paw on the window sill and they cry out that they will not let him in because his paws are black and their mother's are white.

The wolf leaves again and this time he goes to a baker and has the baker rub some dough on his paws. Then the wolf goes to the miller. The miller hears the wolf's request to powder his paws with flour to make them white and initially refuses. He can see that the wolf must want to trick someone with a request like that. The wolf threatens the life of the miller and his family and so the baker helps the wolf in his deceit anyway.

Then the miller was afraid, and made his paws white for him. Truly, this is the way of mankind.

An interesting note from the brothers Grimm is on the selfishness of self-preservation. The wolf then returns and tells the children that he is their mother returned from shopping and the little goats hear the sweet voice and see the white paws and so they open the door. As the wolf barges in they realize their terrible mistake. The children scramble and run and hide but the wolf sniffs out and devours each one by one save for the youngest. The youngest had chosen as his hiding place a clock. This is highly symbolic for reasons I will touch on later, but suffice to say hiding in a physical representation of the concept of time allows him to hide from death while his siblings were all killed.

Then the wolf was full and content and so wandered off into a nearby meadow, bloated and pregnant looking with six kids inside him, and went to sleep. The mother returned home to find the door thrown open and all of the house in disarray but most importantly all of her children were gone. She searched for them and called for them by name and it was only when she got to the youngest that she heard a response. She found him hiding in the clock and scooped him out, he then told her everything. The mother wept for her children. Then mother and child went and found the wolf dead to the world in the pasture. He was not completely still though for she could see movement in his belly, her children still lived. She had the youngest kid fetch her sewing supplies and, using the domestic tools of her home and hearth, she performed a simple surgery on the wolf and brought her children one by one back into the light of day. In his greed whilst devouring the children he had swallowed each of them whole and so they were unhurt. The children danced in joy to be free, "like a tailor at his wedding."

She then had the children fetch rocks for she did not wish the wolf to realize that the children were missing and so refilled the space in the wolf's stomach with the stones the children brought and sewed the wolf back up. This is very like the punishment given the wolf in Grimm's version of Little Red Riding Hood. He too was cut open to free Red and her grandmother and was refilled with stones and sewn back up. When the wolf awoke later he was groggy and thirsty and as he got unsteadily to his feet the rocks inside him shifted and knocked together. As the wolf went in search of drink he said to himself:

\author{
"What rumbles and tumbles \\ Against my poor bones? \\ I thought 'twas six kids, \\ But it feels like big stones."
}


When he came upon a well he leaned over to have a drink but the weight in his stomach pulled him much further than he expected and he toppled into the life-giving waters. There the stones in his stomach pulled him down to the bottom and he drowned. When the kids saw this all seven of them with their mother got in a circle and danced around the well and sang, "The wolf is dead! The wolf is dead!" And so the seven little goats were safe with their mother once more.

There are many different interpretations of this fairy tale depending on whom you ask. If you asked Sigmund Freud he thought this fairy tale symbolized the fear that children have of their fathers who devoured and used versus their mother that cared and nurtured. The problem with this interpretation is that the male figure is not the father of the goats; he is not even the same species. He is a male figure though, and the only one provided in the course of the narrative. It remains though that the danger comes from an outside source and the sanctity of the family provides safety, protection and salvation for its children.

This fairy tale bears a resemblance not to just to myth but to many other fairy tales as well. It is similar to the tale of the Three Little Pigs, they too had a wolf using tricks to gain admittance and devour the inhabitants of the house. Only instead of having the wolf fail to enter many times, the pigs instead fail to stop him, to their varying levels of dismay depending on the version you read. Bruno Bettleheim believes that the Three Little Pigs is a manifestation of a child's fears of taking too much. Children devour everything in their path at times and some of these fairy tales that feature the big bad wolf show what can happen if you take too much are too selfish and thus share the big bad wolf's fate in each of these fairy tales. The danger does not from without in this fairy tale, but is an expression of a danger found within.

I said at the beginning of this post that this fairy tale featured many mythical elements of life and death. In many ways it bears a strong resemblance in fact to a specific myth, that of Cronus. In that myth the god devoured his own children one by one and was tricked into thinking his youngest, Zeus had been eaten by him as well. This was not so because his wife Rhea had tricked him by giving him nothing but a stone wrapped in swaddling to eat. Later Zeus freed his siblings, in some myths by forcing Cronus to drink something to make him regurgitate them, in others Zeus cut his father open, just like in this fairy tale. Cronus devoured his children because he wanted to stop the progress of time; he wanted to stifle the emergence of the next generation so that his own might reign longer. In fact in modern-day Cronus is often depicted as Father Time. Now do you see why it was so interesting that the youngest survived by hiding in a clock?

The other popular fairy tale it is similar to is The Goat and Her Three Kids. This is a Romanian literary fairy tale that was written several decades after the brothers Grimm passed away. Instead of seven, there are three kids. The oldest is hardheaded and outspoken and is the first to die, the youngest is quiet and obedient and is spared. There was some squabbling in YouTube comments over which is the "true" version of the fairy tale and while the Grimm tale does predate it I'm not even sure that can provide a satisfactory answer. Most fairy tales have bits and pieces scattered back so far and so wide that finding an original anything is often literally impossible. Wolves or other monsters eating children or stones or even being turned into stone are common motifs, as are kids of various species and ages being warned against wolves and their tricks, and parents attempting to protect their young with knowledge and songs and wisdom and wile. These all are to be found in every culture in one form or another. It is an overarching theme of familial protection and instinct, protect the young ones from death that we all share regardless of era or language. It is in everyone's fairy tales if you look enough.

\section{Translation Methods of Analysis.}

1. The method of functional analysis; which tries to interpret the role of style in the overall structure of the literature work.

2. The method of psychological and literary analysis is related with the close reading of the text. It combines historical, cultural and aesthetical information with the linguistic one.

3. The method of statistical analysis has to do with the amount of stylistic indicators used in the text, being compared with another text that serves as a standard.

4. The method of key words is related to the repeated use of key words and key phrases, in certain contexts, for certain purposes.

\section{Functional Based Approach of translation}

In his Textbook of translation,Peter Newmark discusses translation using in part a scale that has become well established in linguistics with the work of Michael Halliday.It should be noted that Hallidayan linguistics also informs much of Mona 
Baker's influentual In other words, wich too examines translation at different levels although in Baker's case it is levels of equivalence.

The unit of translation is normally the linguistic unit in wich the translator uses when translating.Translation theorists have proposed various units,from individual word and group to clause and sentence and even higher levels such as text and intertextual levels. Importantly, Newmark makes the crucial point that all lengths of language can,at different moments and also simultaneously,be used as units of translation in the course of the translation activity. While it may be that the translator most often works at the sentence level,paying specific attention to problems raised by individual words or groups in that context,it is also important to take into account the function of the whole text and references to extratextual features. These are crucial areas that will be treated in more depth as this book develops.

John Catford was the first schoolar to use the term in his A linguistic Theory of Translation. His definition of shifts is 'departures from formal correspondence in the process of going from th SL to the TL.The distinction drawn between formal correspondence and textual equivalence will be crucial and relates to Saussure's distinction. Naom Chomsky was probably right in categorically excluding activities such as translation form the purview of this own research into syntactic structures.And so called linguistics oreinted translation theory has not interacted well with translation practise simply because it has systematiclly sought neatness of categories at the expense of being true to what peoplem say or do with language,which is what gets translated ultimately.A formal correspondent is defined by Catford as any TL category wich can be said to occupy,as nearly as possible,the same place in the economy of the TL as the given SL category occupies in the SL

Catford was the first to use the term shift,but the most comprehensive taxonomy of translation shifts,based on their translation procedure,was set out by the Canadinians Jean-Paul Vinay and Jean Darbelnet in their "A Comparative Stylistics of French and English". They approach the subject from the point of view of comparative or contrastive stylistics,using parallel non-translated as well as translated texts,they described a detailed and systematic model for the analysis and comparison of a ST-TT pair.The first step involves identification and numbering of the ST units and the units of translation. This is followed by a matching of the two.

Identifying that a shift has taken place leads to questions such as what kind of shift,what form of classification we can use and what the importance of the shifts is.Vinay and Darbelnet's categorization of translation procedures is very detailed.They name two methods covering seven procedures:

1.direct translation,wich covers borrowing,calque and literal translation.

2.obligue translation, wich is transpostion, modulation,equivalence and adaption.

Nida's two type of meaning:

1.Referential menaing, wich deals with the words as signs or symbols.

2.Connotative meaning,the emotional reaction engendered in the reader by word.

The key problem for the translator is the frequent lack of one to one matching accross languages. Not only does the signifier change accross languages but each language depicts reality differently.Some concepts are very language or culture specific Jakobson may have claimed that any concept can be rendered in any language,but that still does not help the translator find an easy useable equivalent for Halloween in Mandarine Chinese nor an acceptable translation of say in the Chuj language of Guatemala where the truthfulness of the statement is crucial.Nida attempted to overcome this problem by adopting then current ideas from semantics for the analysis of meaning accross the languages.

The other area explored by Nida is connotative meaning,the emotional respondse evoked in the hearer.For instance,on various occassions in St John gospel,the Greek word gunai is translated as woman in the Old King James version but as mother in the New English Bible.The justification for this change is the positive connotation of the Greek wich the translators felt,merited a similarly positive translation equivalent. This is a much more difficult area to investigate objectively.Nevertheless,Osgood,Suci and Tannenbaum did carry out an important study on what they term "semantic space",asking respondents to assess words according to clines of avaluation,potency and activity. This is taken by Nida and Taber who use the good-bad scale and add a scale of formality.

Gideon Toury view norms as translation behavior typically obtaining under specific socio-cultural or textual situations. These TT oriented norms encompass not only translation strategy but also how ,if at all.a TT fits into the literary 
and social culture of the target system.Other norms are those proposed by Chesterman namely "product and expectancy norms" and "professional norms"

Particularly within prestigious translation traditions,translators are known to have been able to exercise absolute power to exclude a reader directly conciously. This is achieved through selectively engaging in such innocent sounding translation procedures as free translatio,heavy glossing,gisting or compensation.Similarly,real or imaniged target norms can also turn translation into an ideological weapon for excluding an author by resorting to such ostensibly harmless procedures as omission or normalization ,often in the service of such seemingly noble goals as sustaining fluency ,combating boredom. Translators themselves may fall victim to the exercise of power by ruthless editors or unthinking censors.

\section{Comparison of English version with Albanian version.}

We can notice that in most of sentences there is formal equivalence between both texts because both languages operate with grammatical units at five ranks: sentence, clause, group, word, and morpheme. For example:

"We will not open the door," cried they; "you are not our mother, she has a delicate and sweet voice, and your voice is hoarse; you must be the wolf."

Nuk ta hapim, jo. Ti s'je nena jone. Ajo e ka zerin te holle e te embel, kurse ti e ke te trashe e te ashper. Ti je ujku, prandaj ik, se nuk ta hapim! (Vellezerit Grim, "Ujku dhe shtate kecat", f. 135)

"Dear children," said she, "I am going out into the wood; and while I am gone, be on your guard against the wolf, for if he were once to get inside he would eat you up, skin, bones, and all. The wretch often disguises himself, but he may always be known by his hoarse voice and black paws."

Degjoni, o kecat e mi, une do te shkoj ne pyll e do t'ju sjell te hani plot te mira. Ju rrini vete ketu ne shtepi, po hapni syte e kini mendjen mos ia celni deren ujkut, se, po hyri Brenda, ju hengri e ju perpiu me gjithe kocka! Ai do te perpiqet t'ju genjeje e te shtihet si tjeterkush, po ju do ta njihni nga zeri i trashe dhe nga kembet e zeza ge ka. (Vellezerit Grim, "Ujku dhe shtate kecat", f. 135)

If we compare these sentences we notice that there is formal equivalence between by his hoarse voice and black paws." and zeri i trashe dhe nga kembet e zeza qe ka, because_both sentences operate with same grammatical units. While between "Dear children" and Degioni, o kecat there is textual equivalence. In English language it says Dear children (the author has used the word children for the little goats in the entire story while in Albanian language the author has used the word "kecat"). In Albanian translation we notice do t'ju sjell te hani plot te mira which is not noticed at the Source Text [the translator wants to show the good care and that it is the parent (in our case the goat is both the mother and the father) who has to provide food for its children and protect them] and the little goats are looking forward their mother to come and bring them good things to eat. hoarse voice and black paws have referential meaning. The author uses the words "hoarse voice and black paws" which represents evil creature even from his black color. In Albanian translation he uses "zeri i trashe dhe nga kembet e zeza" because children are afraid of it. The author implies the idea that their mother has a soft voice and white paws. "White" for purity. "Soft" for sweet voice.

"Open the door, my dear children, your mother is come back, and has brought each of you something." Hapeni, kecat e mi, hapeni! Jam une, nena juaj, hapeni shpejt, se ju kam sjelle te gijitheve giera te shijshme per te ngrene. (Vellezerit Grim, "Ujku dhe shtate kecat", f. 135)

"Each of you" and "te gjitheve" has a textual equivalence because the formal equivalence would be "secilit nga ju". In English version we notice "something" and in Albanian version gjera te shijshme per te ngrene. Translator has changed the meaning in order to make it softer and more beautiful for the ear of the child. Translator has changed the word "and" with "se" instead of "because" in order to adapt it with the context because the context in the sentences differs.

"Open the door, my dear children, your mother is here, and has brought each of you something."

Hapeni, hapeni, o kecat e mi, se jam une, nena juaj, dhe ju kam sjelle plot te mira per te ngrene. (Vellezerit Grim, "Ujku dhe shtate kecat", f. 136) 
Still in this sentence we notice that in English version the author uses the word "children" while in Albanian version it is used the word little goats "kecat". In English version the author wants to represent the idea of a family of people, the old goat personifies the mother and the little goats personify the children. While in Albanian version the author speaks in the old goat's point of view. There is textual equivalence between the two sentences. We also notice again the use of "something" in English version to represent the food or goodies, while in Albanian version the translator has made it sound more beautiful by using" plot te mira per te ngrene".

"Miller," said he, "strew me some white meal over my paws." But the miller refused, thinking the wolf must be meaning harm to someone.

Aman, o mulis, hidhme pak miell ne kembe! Mullisi u step dhe mendoi me vete: Ah, c'do ti bjere me qafe ndokujt kjo egersire! (Vellezerit Grim, "Ujku dhe shtate kecat", f. 136)

The first thing we notice is that in the source text there are only two sentences while in the target text there are three sentences and this because of grammatical rules of Albanian language that differ from those of English language. Another thing is that the translator uses the word Aman to describe a polite request, to teach to students how to make a request. In English version the miller refused, thinking the wolf must be meaning harm to someone differs from the Albanian version. In Albanian version the translator says that the man "u step dhe u mendua" not "refused". Albanians usually doubt and think about something without being noticed for suspecting on the other "person" and then reacting. "strew me some white meal over my paws" and hidhme pak miell ne kembe is an example of Formal Equivalence.

"Here I am, mother," a little voice cried, "here, in the clock-case."

Memeze, une jam ketu, ketu Brenda ne sahat te murit. (Vellezerit Grim, "Ujku dhe shtate kecat", f. 138)

Then she cut the wolf's body open, and no sooner had she made one snip than out came the head of one of the kids, and then another snip, and then one after the other the six little kids all jumped out alive and well, for in his greediness the rogue had swallowed them down whole.

From this we can somehow understand the idea of death and rebirth. This is about a myth of Cronus. In that myth the god devoured his own children one by one and was tricked into thinking his youngest, Zeus, had been eaten by him as well. This was not so because his wife Rhea had tricked him by giving him nothing but a stone wrapped in swaddling to eat. Later Zeus freed his siblings, in some myths by forcing Cronus to drink something to make him regurgitate them, in others Zeus cut his father open, just like in this fairy tale. Cronus devoured his children because he wanted to stop the progress of time, he wanted to stifle the emergence of the next generation so that his own might reign longer. In fact in modern-day Cronus is often depicted as Father Time. That's why the youngest survived by hiding in the clock-case.

\section{Conclusions}

In conclusion to this article is important to understand the value of translation in communicating such educative values as fairy tales carry. Translation as a process and mean of communication serves to have such value. It is indispensable to many researchers of many fields but more importantly to educators and editors of such children texts. The proper translation of a fairy tale is a new mean of education in transmitting values that are common to many cultures. Even though each fairy tale contains individual cultural context common grounds are found. These grounds are found in literature, sociology, child psychology and educational sciences. As Europe is set to join in common values this is the case of raising future generations with common values and understandings. This is the main reason why translations and Translation Studies are part of all interdisciplinary researches and studies.

\section{References}

English version

(http://www.worldoftales.com/fairy tales/Brothers Grimm/Grimm household tales/The wolf and the seven little goats. html).

Albanian version ( Vellezerit Grim, Ujku dhe shtate kecat, f. 135, f. 136, f. 138, f. 139).

Bassnett-McGuire. 1980. Translation Studies. New York: Mathuen \& Co. Ltd. 
Bell, Roger T. 1991. Translation and Translating: Theory and Practice. London: Longman Group Ltd.

Brislin, Ricard. W. 1976. Translation: Application and Research. New York: Gardner Press Inc.

Bruno Bettelheim's Uses of Enchantment and Abuses of Scholarship, Alan Dundes, The Journal of American Folklore Vol. 104, No. 411

(Winter, 1991), pp. 74-83, Published by: American Folklore Society.

Catford, J.C. 1965. A Linguistic Theory of Translation. London: Oxford University Press.

Goodenough, Ward H. 1964. "Cultural Anthropology and Linguistics" in D. Hymes (ed). Language in Culture and Society. A Reader in Linguistics and Anthropology. New York: Harper \& Row.

Halliday \& Hansan (1985), Language: Context and Text. Burwood, Vic; Deaken University.

Hatim, Basil and Mason, lan. 1990. Discourse and the Translator. Longman: Longman Group Limited.

House, Juliane (1997). Translation Quality Assessment: A Model Revisited. Tübingen: Narr.

Hymes. Dell. (ed). Language in Culture and Society. A Reader in Linguistics and Anthropology. New York: Harper \& Row.

Lauscher, S. (2000). "Translation quality assessment: Where can theory and practice meet?" Maier (2000), 149-168.

Mc Guire, S.B. 1980. Translation Studies. Methuen London and New York.

Munday Jeremy, Routledge Companion to Translation Studies, Revised Edition, 2009.

Newmark, Peter. 1991. About Translation. Clevedon: Multilingual Matters Ltd.

Nida, Eugene A., and Taber, Charles R.. 1982. The Theory and Practice of Translation. Leiden: E.J. Brill

Nord, Ch. 1997 Translating as a Purposeful Activity: Functionalist Approach Explained. Manchester, UK \& Northampton MA: St. Jerome Publishing.

Reiss, Katharina. "Type, Kind and Individuality of Text: Decision Making in Translation." 1971.

Ristani, V "Çeshtje stilistike te leksikut gjate perkthimit te veprave te Çarls Dikensit" disertacion, f.83 1996, Tiranë

Snell-Hornby, Mary. 'An Integrated Approach to Translation', John Benjamins, Amsterdam, 1988. 